\title{
A reflexive educational model for design practice with rural communities: the case of bamboo product makers in Cuetzalan, México.
}

\author{
Keywords \\ Buen Vivir, Design Education, Design Practice, Emergent Practices, Transition Design.
}

In the '60s and '70s, a global economic and technological development plan for "undeveloped" countries defined the base of the professionalization process of industrial design in Latin America. Since then, many scholars have revised the industrial design practice and proposed new ways to reinterpret Latin American design according to current perspectives about the context and territory. This research strives on a reflexive educational model based on a socio-technical system's understanding for a mixed craft-industrial design practice with rural communities in Mexico. By combining post and decolonial perspectives and critical theories of neoliberalism in the design field; and analyses of the design education process inside the rural communities of bamboo product makers in Cuetzalan (Puebla, México), it is possible to unravel the translation agency of designers (also as individuals with personal and professional interests) between the global economic system pressures and internal beliefs and positions of communities. Following Arturo Escobar's (2007, 2013, 2017) and Walter Mignolo's (2013) ideas, the design practice in Latin America is highly questionable when it tries to involve rural or social perspectives due to the influence of the development's regimes of representation. These regimes vigorously promote the generation of economic wealth from economic and technological development, primarily based on a globalized neoliberal logic. As Professor Juan Camilo Buitrago shows in the Colombian case, many universities were linked to government economic policies "due to the need to align themselves with the projects that the State was mobilizing based on industrialization to encourage exports." (2012, p. 26). This idea is still valid since public and private universities constantly compete for economic resources that they exchange with applied knowledge that points to the development of various economic sectors. Numerous studies attempt to reconcile academic epistemological and ontological forms with rural ways of understanding the world. Regardless of these efforts, it is necessary to highlight that professional design education has barely incorporated these reflections within its institutional academic structures. This work has been part of a series of university-level courses that mix experiences and perspectives between Anahuac University final year design students and the Tosepan Ojtatsentekitinij (bamboo workshop) members. The current research considers the participation of all the actors involved in the educational process (directors, lecturers, and students) and the people close to the bamboo transformation processes in Cuetzalan. The course is divided into three phases. First, students and professors discuss critical topics about complex systems and wicked problems, participatory methodologies, capitalism and globalization, non-western knowledge, social power dynamics, and Socio-technical systems. The second phase involves independent and guided fieldwork to share thoughts and intentions with the bamboo material and its possible applications. Lastly, there are different creation, experimentation, and exposition moments where each actor could share comments about all the experiences. The results intended to provide analytical tools that allow design students and educational staff members to deconstruct their economical-industrial roots to tend bridges that harmonize imaginative and creative attitudes between designers and rural craftspersons. 